\title{
Electrochemical p erformance of La2NiO4+ס- Ce0.55La0.4502- $\delta$ as a promising bifunctional oxygen electrode for reversible solid oxide cells
}

Pengzhang Li ( 15 b911005@hit.edu.cn )

Jingdezhen Ceramic Institute https://orcid.org/0000-0003-1189-9392

\section{Wei Yang}

Jingdezhen Ceramic Institute

Chuanjin Tian

Jingdezhen Ceramic Institute

Wenyan Zhao

Jingdezhen Ceramic Institute

Zhe Lü

Harbin Institute of Technology

Zhipeng Xie

Tsinghua University

Chang-An Wang

Tsinghua University

\section{Research Article}

Keywords: La2NiO4+ס, oxygen electrode, electrochemical performance, reversible solid oxide cells

Posted Date: December 10th, 2020

DOl: https://doi.org/10.21203/rs.3.rs-52270/v2

License: (9) This work is licensed under a Creative Commons Attribution 4.0 International License.

Read Full License 


\title{
Electrochemical performance of $\mathrm{La}_{2} \mathrm{NiO}_{4+\delta}-\mathrm{Ce}_{0.55} \mathrm{La}_{0.45} \mathrm{O}_{2-\delta}$
}

\section{as a promising bifunctional oxygen electrode for reversible}

\section{solid oxide cells}

Pengzhang $\mathrm{LI}^{\mathrm{a}, *}$, Wei YANG ${ }^{\mathrm{a}}$, Chuanjin TIAN", Wenyan ZHAO ${ }^{\mathrm{a}}$, Zhe Lüb ${ }^{\mathrm{b}}$, Zhipeng $\mathrm{XIE}^{\mathrm{a}, \mathrm{c}}$, Chang-An WANG ${ }^{\mathrm{a}, \mathrm{c}}$

${ }^{a}$ School of Materials Science and Engineering, Jingdezhen Ceramic Institute, Jingdezhen 333403,

China;

${ }^{b}$ School of Physics, Harbin Institute of Technology, Harbin 150001, China;

${ }^{c}$ State Key Laboratory of New Ceramics and Fine Processing, School of Materials Science and Engineering, Tsinghua University, Beijing 100084, China

\begin{abstract}
In this work, $\mathrm{La}_{2} \mathrm{NiO}_{4+\delta}-\mathrm{xCe} \mathrm{e}_{0.55} \mathrm{La}_{0.45} \mathrm{O}_{2-\delta}$ (denoted as $\mathrm{LNO}-\mathrm{xLDC}$ ) with various LDC contents $(\mathrm{x}=0,10,20,30$ and 40 , wt $\%)$ were prepared and evaluated as bifunctional oxygen electrodes for reversible solid oxide cells (RSOCs). Compared with the pure LNO, the optimum composition of LNO-30LDC exhibited the lowest polarization resistance $\left(R_{\mathrm{p}}\right)$ of 0.53 and $0.12 \Omega \cdot \mathrm{cm}^{2}$ in air at 650 and $750{ }^{\circ} \mathrm{C}$, respectively. The enhanced electrochemical performance of LNO-30LDC oxygen electrode was mainly attributed to the extended triple phase boundary and more oxygen ionic transfer channels. The hydrogen electrode supported single cell with LNO-30LDC oxygen electrode displayed peak power densities of 276, 401 and 521 $\mathrm{mW} \cdot \mathrm{cm}^{-2}$ at 700,750 and $800{ }^{\circ} \mathrm{C}$, respectively. Moreover, the electrolysis current
\end{abstract}

\footnotetext{
${ }^{*}$ Funding projects: Science and Technology Project of Jiangxi Provincial Education Department (GJJ190734);

The National Natural Science Foundation of China (51962015).

Corresponding authors: LI Pengzhang (1990-), Male, Ph. D., Lecturer.

E-mail address: 15b911005@hit.edu.cn
} 
density of the single cell demonstrated $526.39 \mathrm{~mA} \cdot \mathrm{cm}^{-2}$ under $1.5 \mathrm{~V}$ at $800{ }^{\circ} \mathrm{C}$, and the corresponding hydrogen production rate was $220.03 \mathrm{ml} \cdot \mathrm{cm}^{-2} \cdot \mathrm{h}^{-1}$. The encouraging results indicated that LNO-30LDC was a promising bifunctional oxygen electrode material for RSOCs.

Keywords: $\mathrm{La}_{2} \mathrm{NiO}_{4+\delta}$; oxygen electrode; electrochemical performance; reversible solid oxide cells

\section{Introduction}

Reversible solid oxide cells (RSOCs) are promising energy storage and regeneration devices, which have attracted worldwide attention due to its multi-function, high energy, low pollution and so on ${ }^{[1,2]}$. RSOCs are capable of operation in the solid oxide fuel cell (SOFC mode) for electricity generation from fuel as well as the solid oxide electrolysis cell (SOEC mode) for hydrogen generation from electrolysis of steam ${ }^{[3,4]}$. However, the polarization loss of the bifunctional oxygen electrode is the key factor limiting the overall performance of RSOCs, which mainly dominated by its electrocatalytic activities for both the oxygen reduction reaction (ORR) and oxygen evolution reaction $(\mathrm{OER})^{[5,6]}$. Considerable efforts have been devoted to reduce the polarization loss of the oxygen electrode by exploring novel materials $^{[7,8]}$. However, oxygen electrode materials with satisfactory electrochemical performances for RSOCs are sill elusive.

Alternatively, $\mathrm{La}_{2} \mathrm{NiO}_{4+\delta}(\mathrm{LNO})$ as the mixed ionic and electronic conductor (MIEC) material with the $\mathrm{K}_{2} \mathrm{NiF}_{4}$-type structure has been regarded as a promising candidate oxygen electrode material due to its moderate thermal expansion coefficient $\left(\sim 13.0 \times 10^{-6} \mathrm{~K}^{-1}\right)$, high oxygen ion conductivity $\left(\sim 0.02 \mathrm{~S} \cdot \mathrm{cm}^{-1}\right.$ at $\left.700{ }^{\circ} \mathrm{C}\right)$ and 
favorable electrochemical performance caused by the additional two phase boundary $(2 \mathrm{~PB})^{[9-11]}$. The crystal structure of LNO consists of alternating stacked LaO rocksalt layers and $\mathrm{LaNiO}_{3}$ perovskite layers along the $c$ direction ${ }^{[12,13]}$. Moreover, in order to reduce the structural stress between the $\mathrm{La}-\mathrm{O}$ and $\mathrm{Ni}-\mathrm{O}$ bondings, excess oxygen (denoted as $\delta$ ) can accommodate into LaO rocksalt layers, which lead to the high ionic conductivity due to the migration of interstitial oxygen in rocksalt layers ${ }^{[14-16]}$. The electrochemical performance of LNO oxygen electrode has been investigated on SDC substrates, which demonstrated a low polarization resistance of $0.38 \Omega \cdot \mathrm{cm}^{2}$ at 800 ${ }^{\circ} \mathrm{C}^{[17]}$. In addition, LNO oxygen electrodes with thickness varying from 5 to $30 \mu \mathrm{m}$ were also evaluated and confirmed the electrocatalytic properties of LNO electrode with a thickness of about $20 \mu \mathrm{m}$ achieved the lowest polarization resistance $(0.24$ $\Omega \cdot \mathrm{cm}^{2}$ at $\left.800{ }^{\circ} \mathrm{C}\right)^{[18]}$. In contrast, the influence of microstructure on electrochemical performance of LNO electrode was also evaluated and indicated the role of surface diffusion of oxygen ${ }^{[19,20]}$. Furthermore, adding various electrolyte compositions (such as $\mathrm{Sm}_{0.2} \mathrm{Ce}_{0.8} \mathrm{O}_{1.9}(\mathrm{SDC}), \mathrm{Zr}_{0.84} \mathrm{Y}_{0.16} \mathrm{O}_{2-\delta}(\mathrm{YSZ})$ and $\mathrm{Ce}_{0.9} \mathrm{Gd}_{0.1} \mathrm{O}_{1.95}$ (GDC)) to form composite oxygen electrode is a common way to further improve the electrode/electrolyte/gas triple phase boundary $(3 \mathrm{~PB})^{[21,22]}$. Hence, composite oxygen electrode prepared by LNO infiltration into porous electrolyte backbone or physically mixing the pristine materials exhibited improved performance. Although the LNO itself was thermodynamically stable, the possible solid state interaction between various components in LNO-based composite electrodes may occur at high temperature ${ }^{[23]}$. The reactivity test between LNO and GDC at $1200{ }^{\circ} \mathrm{C}$ for $1 \mathrm{~h}$ and 800 
${ }^{\circ} \mathrm{C}$ for $250 \mathrm{~h}$ conformed the interphase formation ${ }^{[24]}$. Decomposition of LNO in LNO-SDC composites was also observed after sintering at $1300{ }^{\circ} \mathrm{C}$ for $5 \mathrm{~h}$, which lead to the formation of Sm, La co-doped ceria $\mathrm{Sm}_{0.2} \mathrm{La}_{0.23} \mathrm{Ce}_{0.57} \mathrm{O}_{2-\delta}{ }^{[25]}$. Furthermore, a thermodynamics-based design for $\mathrm{LNO}: \mathrm{La}_{\mathrm{x}} \mathrm{Ce}_{1-\mathrm{x}} \mathrm{O}_{2-\delta}$ composite indicated the improved phase stability ${ }^{[26]}$.

In this work, a series of $\mathrm{La}_{2} \mathrm{NiO}_{4+\delta}-\mathrm{xLa} 0.45 \mathrm{Ce}_{0.55} \mathrm{O}_{2-\delta}$ (denoted as $\mathrm{LNO}-\mathrm{xLDC}$ ) were prepared by mixing LNO and LDC in various weight ratios. The electrochemical properties of LNO-xLDC oxygen electrodes were systematically investigated in detail to determine the optimal LDC content in the composite. The effects of LDC addition on the microstructures and electrochemical performances of oxygen electrodes were also discussed. Furthermore, the electrochemical properties of the hydrogen electrode supported single cell with the LNO-30LDC oxygen electrode was investigated both in the SOFC mode and SOEC mode at $700-800^{\circ} \mathrm{C}$.

\section{Experimental}

\subsection{Preparation of powders}

All of the starting chemicals were analytical grade, which was used directly without any further purification. $\mathrm{La}_{2} \mathrm{NiO}_{4+\delta}(\mathrm{LNO})$ powders were synthesized by the sol-gel method using $\mathrm{La}\left(\mathrm{NO}_{3}\right)_{3} \cdot 6 \mathrm{H}_{2} \mathrm{O}$ (Guoyao Chemical Regent Co., Ltd., Shanghai, China) and $\mathrm{Ni}\left(\mathrm{NO}_{3}\right)_{2} \cdot 6 \mathrm{H}_{2} \mathrm{O}$ (Guoyao Chemical Regent Co., Ltd., Shanghai, China) as starting materials. All metal nitrates in the requisite stoichiometric ratio were dissolved in distilled water, followed by the introduction of citric acid as the complexing agent at a molar ratio of 1:1.5 for the total metal ions and citric acid. The solution was heated at 
$80{ }^{\circ} \mathrm{C}$ for $4 \mathrm{~h}$ under stirring and then dried at $200{ }^{\circ} \mathrm{C}$ for $12 \mathrm{~h}$ in order to remove residual water. Subsequently, the dry gel was successively pre-calcined at $800{ }^{\circ} \mathrm{C}$ for 4 $\mathrm{h}$, ground for $1 \mathrm{~h}$ and then calcined at $1100{ }^{\circ} \mathrm{C}$ for $4 \mathrm{~h}$ in air to obtain the final black LNO powders. $\mathrm{Ce} 0.55 \mathrm{La} 0.45 \mathrm{O}_{2-\delta}(\mathrm{LDC})$ and $\mathrm{Sm}_{0.2} \mathrm{Ce}_{0.8} \mathrm{O}_{1.9}$ (SDC) powders were also prepared by the same procedure as previously reported, respectively ${ }^{[27]}$. The final calcination condition of LDC and SDC powders was $800{ }^{\circ} \mathrm{C}$ for $4 \mathrm{~h}$. The composite samples were prepared by adding LDC powders in the amount of 10, 20, 30 and 40 wt.\% to LNO powders (LNO-xLDC). The mixtures were ground using a mortar for 2 $h$ to ensure uniform distribution.

\subsection{Fabrication of symmetric cells and single cells}

The electrochemical performance was evaluated based on symmetrical cells with a LNO-xLDC $|\mathrm{SDC}|$ LNO-xLDC configuration. The SDC substrates for symmetrical cells were prepared with SDC powders via dry pressing uniaxially at $300 \mathrm{MPa}$ for 1 min and then sintering at $1400{ }^{\circ} \mathrm{C}$ for $4 \mathrm{~h}$. The thickness of dense SDC disks was about $350 \mu \mathrm{m}$. The slurry for each composite electrode was prepared by mixing electrode materials with terpineol solution of $7 \mathrm{wt} . \%$ ethylic cellulose in a weight ratio of 7:3. The slurry was coated on the one side of the SDC disk and then calcined at 800 ${ }^{\circ} \mathrm{C}$ for $2 \mathrm{~h}$ in air. Subsequently, the slurry was coated on the other side of the SDC disk as shown in Fig. S1. Finally, the symmetrical cell was calcined at $1100^{\circ} \mathrm{C}$ for $4 \mathrm{~h}$ in air. The area of the oxygen electrode was $0.12 \mathrm{~cm}^{2}$. Moreover, the silver paste (DAD-87, Shanghai Research Institute of Synthetic Resins, China) was coated on surface of the oxygen electrode as current collector. 
The hydrogen electrode supported single cell (NiO-YSZ|YSZ|SDC|LNO-30LDC) was fabricated by the similar procedure as previously described ${ }^{[28]}$. Briefly, $\mathrm{NiO}$ (Inco, Canada) and YSZ powders (TZ-8Y, Tosoh Corporation, Tokyo, Japan) with a weight ratio of 5:5 were mixed uniform and pressed uniaxially at $300 \mathrm{MPa}$. NiO-YSZ disks ( $\sim 350 \mu$ m-thick) were pre-sintered at $1000{ }^{\circ} \mathrm{C}$ for $2 \mathrm{~h}$. Subsequently, the YSZ electrolyte layer ( $25 \mu \mathrm{m}$-thick) was applied onto NiO-YSZ disks using the slurry spin coating method, which were sintered at $1400{ }^{\circ} \mathrm{C}$ for $4 \mathrm{~h}$. The SDC barrier layer ( $\sim 10 \mu$ m-thick) was also coated on the surface of the YSZ layer to prevent the detrimental interaction. Finally, the LNO-30LDC slurry was painted on hydrogen electrode supported half cells and sintered at $1100{ }^{\circ} \mathrm{C}$ for $4 \mathrm{~h}$ to form the porous oxygen electrode layer ( $20 \mu \mathrm{m}$-thick).

\subsection{Characterization on microstructure and electrochemical performance}

Phase compositions of LNO-30LDC was examined by X-ray diffraction (XRD, Rigaku D/max2200, Japan). The surface and cross-section microstructure of oxygen electrodes were observed by a field emission scanning electron microscope (SEM, HitachiSU800, Japan). Energy-dispersive X-ray spectroscopy analysis was applied to observe the distribution of various elements across the interface between the oxygen electrode and electrolyte.

The electrochemical impedance spectra (EIS) measurements of symmetric cells with LNO-xLDC were obtained under open-circuit voltage over the frequency range from $10 \mathrm{mHz}$ to $100 \mathrm{kHz}$ with the AC signal amplitude of $10 \mathrm{mV}$. Moreover, the hydrogen electrode supported single cell using LNO-30LDC as the oxygen electrode 
was tested at the temperature range from 700 to $800{ }^{\circ} \mathrm{C}\left(50^{\circ} \mathrm{C}\right.$ intervals $)$. The single cell was sealed on the top of an alumina tube. For power generation (SOFC mode), dry hydrogen at the flow rate of $50 \mathrm{ml} \cdot \mathrm{min}^{-1}$ was fed to the hydrogen electrode, while the oxygen electrode was exposed to ambient air. Furthermore, for steam electrolysis (SOEC mode), steam with hydrogen carrier gas at a rate of $100 \mathrm{ml} \cdot \mathrm{min}^{-1}$ was fed to the hydrogen electrode. The absolute humidity $(\mathrm{AH}$, the vol.\% of humidity in the total gas volume) of the mixture gas was about 30 vol.\%. Hydrogen generation rate of steam electrolysis was calculated from the Faraday's law, assuming 100\% current efficiency ${ }^{[29,30]}$. The current-voltage curves (I-V) and EIS data of the single cell were collected by an electrochemical workstation (Bio-logic VSP, France).

\section{Result and discussion}

The XRD patterns of LNO-30LDC powders after calcined at 900, 1000 and 1100 ${ }^{\circ} \mathrm{C}$ for $10 \mathrm{~h}$ were presented in Fig. 1. It clearly indicated that all peaks of LNO-30LDC can be identified with a physical mixture of LNO and LDC. No additional peaks were observed. The structures of LNO and LDC in LNO-30LDC after sintered at 900, 1000 and $1100{ }^{\circ} \mathrm{C}$ for $10 \mathrm{~h}$ remained unchanged, which revealed no obvious chemical reaction occurs. Hence, the result confirmed the chemical compatibility between LNO and LDC, which is consistent with the previous report ${ }^{[26]}$.

The surface morphology of various composite oxygen electrodes was observed as shown in Fig. 2. The typical morphology as shown in Fig. 2c displayed that LNO particles were surrounded by the finer LDC particles. Clearly, the particle size of LNO was about 500-1000 nm, while LDC had a smaller particle size (about 100-300 
nm). Sufficient contact between LNO and LDC particles was beneficial to the expansion of $3 \mathrm{~PB}$ areas and the formation of oxygen ion transport channels, which could facilitate their electrocatalytic activities ${ }^{[31]}$.

Furthermore, the cross-section of the symmetrical cell with LNO-30LDC electrode was also observed (Fig. 3a). The LNO-30LDC electrode with a thickness of $22 \mu \mathrm{m}$ was tightly bonded to the surface of the dense electrolyte without any cracks or separation. Energy-dispersive X-ray spectroscopy linear scan analysis across the interface between LNO-30LDC oxygen electrode and SDC electrolyte was also measured as shown in Fig. 3b. Obviously, the content of La and Ni was decreased rapidly at the interface of SDC electrolyte and LNO-30LDC electrode, while the content of $\mathrm{Ce}$ increased sharply, which also indicated that there was no obvious elemental diffusion or detrimental solid state interaction.

The impedance spectra of the symmetric cell with LNO-xLDC oxygen electrodes were measured to evaluate the electrochemical performance of various oxygen electrodes. The high frequency intercept dominated by the ohmic resistance $\left(R_{\mathrm{o}}\right)$ was normalized to zero in Nyquist plots. Fig. $4 \mathrm{a}$ and $4 \mathrm{~b}$ displayed the typical Nyquist plots of symmetrical cells with LNO-xLDC oxygen electrodes at temperature of 650 and $750{ }^{\circ} \mathrm{C}$, respectively. The impedance spectra appears as a obviously asymmetrical and depressed semicircle in shape, inferring contributions from more than one electrode process $^{[32,33]}$. Therefore, the $L R_{\mathrm{o}}\left(R_{1} C P E_{1}\right)\left(R_{2} C P E_{2}\right)\left(R_{3} C P E_{3}\right)$ equivalent circuits (Fig. 4a, $\mathrm{b}$ inset) were implemented to fit the impedance spectra to understand the electrode processes. The fitted parameters of electrochemical impedance spectra were listed in 
Table S1. Here, $L$ is the inductance and total polarization resistance is expressed as $R_{\mathrm{p}}=R_{1}+R_{2}+R_{3} .\left(R_{\mathrm{i}} C P E_{\mathrm{i}}\right)(\mathrm{i}=1,2,3)$ corresponds to related electrode processes, where $R_{\mathrm{i}}$ and $C P E_{\mathrm{i}}$ represents the resistance and the constant phase element, respectively. The equivalent capacitance $(C)$ and relaxation frequency $(f)$ convey critical information of electrode processes, which can be calculated according to the following equations ${ }^{[34,}$ 35]:

$$
\begin{aligned}
& C=\frac{(R \cdot C P E)^{1 / n}}{R} \\
& f=\frac{(R \cdot C P E)^{-1 / n}}{2 \pi}
\end{aligned}
$$

The equivalent capacitance and relaxation frequency can be used as characteristic parameters to distinguish various electrode processes ${ }^{[36]}$. The relaxation frequencies of various electrodes were increased by on order of magnitude with increasing temperature from 650 to $750{ }^{\circ} \mathrm{C}$, which can be assigned to the thermally activated mechanism ${ }^{[32]}$. The equivalent capacitances and of the processes 1,2 and 3 were on the orders of magnitude of $\sim 10^{-4}, \sim 10^{-3}$ and $\sim 10^{-2} \mathrm{~F} \cdot \mathrm{cm}^{-2}$, while the relaxation frequencies of the processes 1,2 and 3 were on the orders of $10^{3}-10^{4}, 10^{2}-10^{3}$ and $10-10^{2} \mathrm{~Hz}$, respectively. Accordingly, the processes 1,2 and 3 can be assigned to electron transfer between the electrode and oxygen species on the surface, adsorption and dissociation of molecular oxygen on the surface of the electrode as well as diffusion of oxygen through the porous electrode ${ }^{[33,34,36]}$. Furthermore, the value of $R_{2}$ accounted for the largest proportion of $R_{\mathrm{p}}$, which indicated that adsorption and dissociation of molecular oxygen on the surface of the electrode made a larger 
contribution to the total polarization resistance.

The polarization resistance $\left(R_{\mathrm{p}}\right)$ of LNO-xLDC oxygen electrodes at 650 and 750 ${ }^{\circ} \mathrm{C}$ decreased with increasing $\mathrm{x}$ from 0 to $30 \mathrm{wt} . \%$ and then increased. Among the evaluated various compositions, LNO-30LDC electrode possessed the lowest $R_{\mathrm{p}}(0.12$ $\Omega \cdot \mathrm{cm}^{2}$ at $750{ }^{\circ} \mathrm{C}$ and $0.53 \Omega \cdot \mathrm{cm}^{2}$ at $650{ }^{\circ} \mathrm{C}$, respectively) as shown in Fig. 4c, which were also lower than the literature data in Table 1.

It should be note that the $R_{\mathrm{p}}$ at $750{ }^{\circ} \mathrm{C}$ of LNO-30LDC oxygen electrode was even comparable with the LNO infiltrated YSZ electrode, which mainly contributed to the effective connection between LNO and LDC particles as well as the expansion of $3 \mathrm{~PB}^{[31,41]}$. The Arrhenius plots of the total $R_{\mathrm{p}}$ for LNO-xLDC composite electrodes displayed in Fig. 4d. The activation energies of LNO, LNO-10LDC, LNO-20LDC, LNO-30LDC and LNO-40LDC was 124.8, 125.1, 118.9, 113.2 and $118.1 \mathrm{~kJ} \cdot \mathrm{mol}$, respectively. The activation energy of LNO-30LDC oxygen electrode was relatively lower than that of LNO cathode $\left(124.8 \mathrm{~kJ} \cdot \mathrm{mol}^{-1}\right)$ in this work as well as the 121.9 $\mathrm{kJ} \cdot \mathrm{mol}^{-1}$ of LNO electrode reported previously ${ }^{[42]}$.

To further explain the mechanism of oxygen reduction reaction, the possible sub-steps of oxygen reduction reaction in LNO and LNO-xLDC oxygen electrode on SDC electrolyte were schematically illustrated in Fig. 5. The overall oxygen reduction reaction on the oxygen electrode can be described as $\frac{1}{2} \mathrm{O}_{2}(\mathrm{~g})+2 \mathrm{e}^{-}=\mathrm{O}^{2-}$, which contains several sub-steps, such as the gaseous oxygen adsorption-dissociation on the oxygen electrode surface $\left(\mathrm{O}_{2}(\mathrm{~g}) \square \mathrm{O}_{2 \text {,ads }}\right.$ and $\left.\mathrm{O}_{2 \text { ads }} \square 2 \mathrm{O}_{\text {ads }}\right)$, the charge transfer process $\left(\mathrm{O}_{\text {ads }}+2 \mathrm{e}^{-}+\mathrm{V}_{\mathrm{O}}^{*} \square \mathrm{O}_{\mathrm{O}}^{\times}\right.$) as well as the ionic oxygen transfer process 
$\left(\mathrm{O}_{3 \mathrm{~PB}}^{2-}+\mathrm{V}_{\mathrm{O}}^{*} \square \mathrm{O}_{\mathrm{O}}^{\times}\right)^{[43]}$. For the pure LNO oxygen electrode (Fig. 5a), the total oxygen electrode surface could be applied as active sites for oxygen reduction reaction, which signified the active region extends from the interface of the oxygen electrode and electrolyte to the entire oxygen electrode surface ${ }^{[44]}$. The electrochemical reactions of the oxygen electrode in the SOEC mode are the inverse to sub-steps in the SOFC mode. Hence, the expansion of the active region also contributes to the enhanced electrochemical performance of the oxygen electrode in SOEC mode ${ }^{[28]}$.

Moreover, the addition of LDC with proper content in LNO not only provided more oxygen ionic transfer channels but also formed more 3PB due to the extensive contact between LNO and LDC particles as shown in Fig. 5b, which played a vital role in the enhanced electrochemical performance of LNO-30LDC (Fig. 5c ${ }^{[17]}$. However, the electronic transfer channels could not be effectively built up for LNO-40LDC with the addition of excess LDC, which lead to the sharp increase of $R_{\mathrm{p}}$. Simultaneously, discontinuous electronic transport channels also resulted in the high ohmic resistance of composite oxygen electrode ${ }^{[45]}$.

Furthermore, the electrichemical performance of LNO-30LDC oxygen electrode was also evaluated using the hydrogen electrode supported single cell (NiO-YSZ|YSZ|SDC|LNO-30LDC). Fig. 6 presented the I-V curves and corresponding I-P curves of the single cell in the SOFC mode with dry $\mathrm{H}_{2}$ as the fuel at $700-800{ }^{\circ} \mathrm{C}$. The open circuit voltage was $1.05 \mathrm{~V}$ at $700{ }^{\circ} \mathrm{C}$. The maximum power densities of the single cell achieved 276, 401 and $521 \mathrm{~mW} \cdot \mathrm{cm}^{-2}$ at 700,750 and 800 ${ }^{\circ} \mathrm{C}$, respectively. Moreover, Fig. 7a displayed the impedance spectra of single cell with 
LNO-30LDC oxygen electrode at various temperatures. $R_{\mathrm{p}}$ was decreased with the increase of operation temperature due to the higher electrocatalytic activity of LNO-30LDC oxygen electrode at the elevated temperature. As can be observed in Fig. 7(b), the intermediate to low frequency range features the dominating process ${ }^{[46]}$. Moreover, the Bode plot peaks shift towards low frequencies with increasing temperature, which mainly corresponds to impedances related to diffusion or mass transport processes ${ }^{[47]}$. Hence, LNO-30LDC oxygen electrode displayed encouraging performance in the SOFC mode.

In order to evaluate the overall performance of the LNO-30LDC oxygen electrode in RSOCs operation, the hydrogen electrode supported single cell was measured at 700-800 ${ }^{\circ} \mathrm{C}$ under both in the SOFC mode and the SOEC mode. When the open circuit voltage was higher than the applied voltage, the cell operated in the SOFC mode and generated electricity with the consumption of fuel. By contrast, when the open circuit voltage was lower than the applied voltage, the cell operated in the SOEC mode and splits $\mathrm{H}_{2} \mathrm{O}$ into $\mathrm{H}_{2}$ and $\mathrm{O}_{2}$ with the consumption of electricity ${ }^{[48]}$. As shown in Fig. 8a, the the open circuit voltage values of the single cell were around $1.01 \mathrm{~V}$, which indicated the cell was well sealed. The slope of I-V curves increased with operation temperature increasing from 700 to $800{ }^{\circ} \mathrm{C}$. Moreover, the electrolysis current density was increasing with the increasing of applied electrolysis voltage from the open circuit voltage to $1.5 \mathrm{~V}$. The current densities achieved 270.86, 445.06 and $526.39 \mathrm{~mA} \cdot \mathrm{cm}^{-2}$ at 700,750 and $800{ }^{\circ} \mathrm{C}$ under applied electrolysis voltage of $1.5 \mathrm{~V}$, respectively. To further reveal the hydrogen generation properties of the single cell 
with LNO-30LDC oxygen electrode, hydrogen production rates can be directly calculated according the measured current data as following equation ${ }^{[29]}$ :

$$
\Delta N_{H_{2}}=\frac{-I}{2 F}
$$

The molar rate of hydrogen generation is expressed as $\Delta N_{H_{2}} . I$ and $F$ is the electrical current and the Faraday's constant, respectively. Hydrogen production rates was $113.22,186.03$ and $220.03 \mathrm{~mL} \cdot \mathrm{cm}^{-2} \cdot \mathrm{h}^{-1}$ at 700,750 and $800{ }^{\circ} \mathrm{C}$ under $1.5 \mathrm{~V}$, respectively. All above very promising results revealed that LNO-30LDC was a good candidate as the oxygen electrode for RSOCs.

\section{Conclusions}

In summary, a series of $\mathrm{La}_{2} \mathrm{NiO}_{4+\delta}-\mathrm{xCe} 0.55 \mathrm{La}_{0.45} \mathrm{O}_{2-\delta}$ composites (LNO-xLDC) with various LDC contents $(\mathrm{x}=0-40, \mathrm{wt} . \%)$ were investigated as oxygen electrodes for RSOCs. The XRD results revealed no other by-product phases occurred in LNO-30LDC after sintering at 900, 1000 and $1100{ }^{\circ} \mathrm{C}$ for $4 \mathrm{~h}$. Proper adding of LDC in LNO-xLDC revealed improved electrochemical performance than that of pristine LNO, which was mainly attributed to the expansion of 3PB and more oxygen ionic transfer channels. LNO-30LDC oxygen electrode displayed the lowest $R_{\mathrm{p}}$ value $(0.12$ $\Omega \cdot \mathrm{cm}^{2}$ ) at $750{ }^{\circ} \mathrm{C}$. Furthermore, the maximum power density of hydrogen electrode supported single cell with LNO-30LDC oxygen electrode achieved $521 \mathrm{~mW} \cdot \mathrm{cm}^{-2}$ at $800{ }^{\circ} \mathrm{C}$. The electrolysis current density of the single cell demonstrated 526.39 $\mathrm{mA} \cdot \mathrm{cm}^{-2}$ under $1.5 \mathrm{~V}$ at $800{ }^{\circ} \mathrm{C}$, and the corresponding hydrogen production rate was $220.03 \mathrm{ml} \cdot \mathrm{cm}^{-2} \cdot \mathrm{h}^{-1}$. All above results suggested that LNO-30LDC was a promising bifunctional oxygen electrode material for RSOCs. 


\section{Acknowledgments}

The authors gratefully acknowledge financials support from the Science and Technology Project of Jiangxi Provincial Education Department (GJJ190734) and the National Natural Science Foundation of China (51962015).

\section{References}

[1] Irvine JTS, Neagu D, Verbraeken MC, et al. Evolution of the electrochemical interface in high-temperature fuel cells and electrolysers. Nat Energ 2016, 1(1): 1-13.

[2] He Z, Zhang L, He S, et al. Cyclic polarization enhances the operating stability of La $0.57 \mathrm{Sr}_{0.38} \mathrm{Co}_{0.18} \mathrm{Fe}_{0.72} \mathrm{Nb}_{0.1} \mathrm{O}_{3-\delta}$ oxygen electrode of reversible solid oxide cells. $J$ of Power Sources 2018, 404: 73-80.

[3] Gómez SY, Hotza D. Current developments in reversible solid oxide fuel cells. Renew Sust Energ Rev 2016, 61: 155-174.

[4] Chen K, Liu SS, Ai N, et al. Why solid oxide cells can be reversibly operated in solid oxide electrolysis cell and fuel cell modes? Phys Chem Chem Phys 2015, 17(46): 31308-31315.

[5] Lee SI, Kim J, Son JW, et al. High performance air electrode for solid oxide regenerative fuel cells fabricated by infiltration of nano-catalysts. J of Power Sources 2014, 250: 15-20.

[6] Tong XF, Ovtar S, Brodersen K, et al. Large-area solid oxide cells with $\mathrm{La}_{0.6} \mathrm{Sr}_{0.4} \mathrm{CoO}_{3-\delta}$ infiltrated oxygen electrodes for electricity generation and hydrogen production. J of Power Sources 2020, 451: 227742.

[7] Mogensen MB. Materials for reversible solid oxide cells. Curr Opin Electrochem 
2020, 21: 265-273.

[8] Zhang Y, Han M, Sun Z. High performance and stability of nanocomposite oxygen electrode for solid oxide cells. Int J Hydrogen Energ 2020, 45(8): 5554-5564.

[9] Zhao K, Xu Q, Huang DP, et al. Electrochemical evaluation of $\mathrm{La}_{2} \mathrm{NiO}_{4+\delta}$-based composite electrodes screen-printed on $\mathrm{Ce}_{0.8} \mathrm{Sm}_{0.2} \mathrm{O}_{1.9}$ electrolyte. J Solid State Electr 2012, 16(8): 2797-2804.

[10] Yoo YS, Choi M, Hwang $\mathrm{JH}$, et al. $\mathrm{La}_{2} \mathrm{NiO}_{4+\delta}$ as oxygen electrode in reversible solid oxide cells. Ceram Int 2015(41): 6448-6454.

[11] Egger A, Schrödl N, Gspan C, et al. $\mathrm{La}_{2} \mathrm{NiO}_{4+\delta}$ as electrode material for solid oxide fuel cells and electrolyzer cells. Solid State Ionics 2017, 299: 18-25.

[12] Hou J, Zhu Z, Qian J, et al. A new cobalt-free proton-blocking composite cathode $\mathrm{La}_{2} \mathrm{NiO}_{4+\delta}-\mathrm{LaNi}_{0.6} \mathrm{Fe}_{0.4} \mathrm{O}_{3-\delta}$ for $\mathrm{BaZr}_{0.1} \mathrm{Ce}_{0.7} \mathrm{Y}_{0.2} \mathrm{O}_{3-\delta}$-based solid oxide fuel cells. $J$ of Power Sources 2014, 264: 67-75.

[13] Nirala G, Yadav D, Upadhyay S. Ruddlesden-Popper phase $\mathrm{A}_{2} \mathrm{BO}_{4}$ oxides: Recent studies on structure, electrical, dielectric, and optical properties. J Adv Ceram 2020, 9(2): 129-148.

[14] Ekaterina K, Kiryl Z, Alexander V, et al. Impact of Oxygen Deficiency on the Electrochemical Performance of $\mathrm{K}_{2} \mathrm{NiF}_{4}$-Type $\left(\mathrm{La}_{1-\mathrm{x}} \mathrm{Sr}_{\mathrm{x}}\right)_{2} \mathrm{NiO}_{4-\delta}$ Oxygen Electrodes. ChemSusChem 2016(9): 1-13.

[15] Huang JB, Gao RF, Mao ZQ, et al. Investigation of $\mathrm{La}_{2} \mathrm{NiO}_{4+\delta}$-based cathodes for SDC-carbonate composite electrolyte intermediate temperature fuel cells. Int $J$ Hydrogen Energ 2010, 35: 2657-2662. 
[16] Amow G, Davidson I, Skinner S. A comparative study of the Ruddlesden-Popper series, $\mathrm{La}_{\mathrm{n}+1} \mathrm{Ni}_{\mathrm{n}} \mathrm{O}_{3 \mathrm{n}+1}(\mathrm{n}=1,2$ and 3 ), for solid-oxide fuel-cell cathode applications. Solid State Ionics 2006, 177(13-14): 1205-1210.

[17] Zhao K, Wang YP, Chen M, et al. Electrochemical evaluation of $\mathrm{La}_{2} \mathrm{NiO}_{4+\delta}$ as a cathode material for intermediate temperature solid oxide fuel cells. Int J Hydrogen Energ 2014, 39: 7120-7130.

[18] Wang YP, Zhao K, Xu Q, et al. Optimization on the electrochemical properties of $\mathrm{La}_{2} \mathrm{NiO}_{4+\delta}$ cathodes by tuning the cathode thickness. Int J Hydrogen Energ 2018, 43: $4482-4491$.

[19] Hildenbrand N, Nammensma P, Blank DHA, et al. Influence of configuration and microstructure on performance of $\mathrm{La}_{2} \mathrm{NiO}_{4+\delta}$ intermediate-temperature solid oxide fuel cells cathodes. $J$ of Power Sources 2013, 238: 442-453.

[20] Sharma RK, Burriel M, Dessemond L, et al. An innovative architectural design to enhance the electrochemical performance of $\mathrm{La}_{2} \mathrm{NiO}_{4+\delta}$ cathodes for solid oxide fuel cell applications. $J$ of Power Sources 2016, 316: 17-28.

[21] Liu ZB, Zhang XM, Huang ZD, et al. Co-synthesized (La0.8Sr0.2) ${ }_{0.9} \mathrm{MnO}_{3}-$ $\mathrm{Y}_{0.15} \mathrm{Zr}_{0.85} \mathrm{O}_{2}$ composite for solid oxide fuel cell cathode. Int J Hydrogen Energ 2016, 41: 21385-21393.

[22] Ai N, Chen $\mathrm{M}$, He $\mathrm{S}$, et al. High performance nanostructured bismuth oxide-cobaltite as a durable oxygen electrode for reversible solid oxide cells. J Mater Chem A 2018, 6(15): 6510-6520.

[23] Vibhu V, Flura A, Rougier A, et al. Electrochemical ageing study of mixed 
lanthanum/praseodymium nickelates $\mathrm{La}_{2-x} \mathrm{Pr}_{x} \mathrm{NiO}_{4+\delta}$ as oxygen electrodes for solid oxide fuel or electrolysis cells. $J$ Energ Chem 2020, 46: 62-70.

[24] Vibhu V, Vinke IC, Eichel RA, et al. $\mathrm{La}_{2} \mathrm{Ni}_{1-\mathrm{x}} \mathrm{Co}_{\mathrm{x}} \mathrm{O}_{4+\delta}(\mathrm{x}=0.0,0.1$ and 0.2$)$ based efficient oxygen electrode materials for solid oxide electrolysis cells. $J$ of Power Sources 2019, 444: 227292.

[25] Cetin D, Poizeau S, Pietras J, et al. Decomposition of $\mathrm{La}_{2} \mathrm{NiO}_{4}$ in $\mathrm{Sm}_{0.2} \mathrm{Ce}_{0.8} \mathrm{O}_{2}-\mathrm{La}_{2} \mathrm{NiO}_{4}$ composites for solid oxide fuel cell applications. Solid State Ionics 2017, 300: 91-96.

[26] Cetin D, Poizeau S, Pietras J, et al. Phase stabilization of $\mathrm{La}_{2} \mathrm{NiO}_{4}$ in $\mathrm{La}_{x} \mathrm{Ce}_{1-\mathrm{x}} \mathrm{O}_{2}: \mathrm{La}_{2} \mathrm{NiO}_{4}$ composites for solid oxide fuel cell applications. Solid State Ionics 2017, 307: 14-20.

[27] Li PZ, Wang ZH, Huang XQ, et al. Enhanced electrochemical performance of co-synthesized $\mathrm{La}_{2} \mathrm{NiO}_{4+\delta}-\mathrm{Ce} 0.55 \mathrm{La} 0.45 \mathrm{O}_{2-\delta}$ composite cathode for IT-SOFCs. $J$ Alloy Compd 2017, 705: 105-111.

[28] Jiang W, Wei B, Lv Z, et al. Performance and stability of co-synthesized $\mathrm{Sm}_{0.5} \mathrm{Sr}_{0.5} \mathrm{CoO}_{3}-\mathrm{Sm}_{0.2} \mathrm{Ce}_{0.8} \mathrm{O}_{1.9}$ oxygen electrode for reversible solid oxide cells. Electrochim Acta 2015, 180: 1085-1093.

[29] Tan Y, Duan N, Wang A, et al. Performance enhancement of solution impregnated nanostructured $\mathrm{La} 0.8 \mathrm{Sr}_{0.2} \mathrm{Co} 0.8 \mathrm{Ni} 0.2 \mathrm{O}_{3-\delta}$ oxygen electrode for intermediate temperature solid oxide electrolysis cells. J of Power Sources 2016, 305: 168-174.

[30] Yang C, Coffin A, Chen F. High temperature solid oxide electrolysis cell employing porous structured ( $\mathrm{La} 0.75 \mathrm{Sr} 0.25) 0.95 \mathrm{MnO}_{3}$ with enhanced oxygen electrode 
performance. Int J Hydrogen Energ 2010, 35(8): 3221-3226.

[31] Santos-Gómez L, Zamudio-García J, Porras-Vázquez JM, et al. Highly efficient La $0.8 \mathrm{Sr}_{0.2} \mathrm{MnO}_{3-\delta}-\mathrm{Ce}_{0.9} \mathrm{Gd}_{0.1} \mathrm{O}_{1.95}$ nanocomposite cathodes for solid oxide fuel cells. Ceram Int 2018(44): 4961-4966.

[32] Wang Y-P, Xu Q, Huang D-P, et al. Survey on electrochemical properties of $\mathrm{La}_{2-\mathrm{x}} \mathrm{Sr}_{\mathrm{x}} \mathrm{NiO}_{4 \pm \delta}(\mathrm{x}=0.2$ and $0.8, \delta>0)$ cathodes related with structural stability under cathodic polarization conditions. Int J Hydrogen Energ 2017, 42(9): 6290-6302.

[33] Zhao K, Xu Q, Huang DP, et al. Microstructure and electrochemical properties of porous $\mathrm{La}_{2} \mathrm{NiO}_{4+\delta}$ electrode screen-printed on $\mathrm{Ce}_{0.8} \mathrm{Sm}_{0.2} \mathrm{O}_{1.9}$ electrolyte. J Solid State Electr 2010, 16(1): 9-16.

[34] Garali M, Kahlaoui M, Mohammed B, et al. Synthesis, characterization and electrochemical properties of $\mathrm{La}_{2-\mathrm{x}} \mathrm{Eu}_{\mathrm{x}} \mathrm{NiO}_{4+\delta}$ Ruddlesden-Popper-type layered nickelates as cathode materials for SOFC applications. Int J Hydrogen Energ 2019, 44(21): 11020-11032.

[35] Kahlaoui M, Inoubli A, Chefi S, et al. Electrochemical and structural study of neodymium nickelate thick film deposited by spin coating on an oxyapatite electrolyte. Ionics 2014, 20(12): 1729-1735.

[36] Wang Y-P, Xu Q, Huang D-P, et al.. Evaluation of $\mathrm{La}_{1.8} \mathrm{Sr}_{0.2} \mathrm{NiO}_{4+\delta}$ as cathode for intermediate temperature solid oxide fuel cells. Int J Hydrogen Energ 2016, 41(15): 6476-6485.

[37] Jeong C, Lee JH, Park M, et al. Design and processing parameters of $\mathrm{La}_{2} \mathrm{NiO}_{4+\delta}$-based cathode for anode-supported planar solid oxide fuel cells (SOFCs). $J$ 
of Power Sources 2015, 297: 370-378.

[38] Choi S, Yoo S, Shin J-Y, et al. High Performance SOFC Cathode Prepared by Infiltration of $\mathrm{La}_{n+1} \mathrm{Ni}_{\mathrm{n}} \mathrm{O}_{3 \mathrm{n}+1}(\mathrm{n}=1,2$, and 3) in Porous YSZ. J Electrochem Soc 2011, 158(8): B995-B999.

[39] Woolley RJ, Skinner SJ. Novel $\mathrm{La}_{2} \mathrm{NiO}_{4+\delta}$ and $\mathrm{La}_{4} \mathrm{Ni}_{3} \mathrm{O}_{10-\delta}$ composites for solid oxide fuel cell cathodes. J of Power Sources 2013, 243: 790-795.

[40] Li Q, Sun L, Zhao H, et al. La1.6Sro.4NiO4 one-dimensional nanofibers as cathode for solid oxide fuel cells. J of Power Sources 2014, 263: 125-129.

[41] Kim YT, Shikazono N. Evaluation of electrochemical reaction mechanisms of La0.6Sr0.4 $\mathrm{CoO}_{3-\delta}-\mathrm{Gd}_{0.1} \mathrm{Ce}_{0.9} \mathrm{O}_{2-\delta}$ composite cathodes by 3D numerical simulation. Solid State Ionics 2018, 319: 162-169.

[42] Lu L, Guo Y, Zhang $\mathrm{H}$, et al. Electrochemical performance of $\mathrm{La}_{2} \mathrm{NiO}_{4+\delta^{-}}$ La $0.6 \mathrm{Sr}_{0.4} \mathrm{Co} 0.2 \mathrm{Fe}_{0.8} \mathrm{O}_{3-\delta}$ composite cathodes for intermediate temperature solid oxide fuel cells. Mater Res Bull 2010, 45(9): 1135-1140.

[43] Zhou J, Chen G, Wu K, et al. $\mathrm{La}_{0.8} \mathrm{Sr}_{1.2} \mathrm{CoO}_{4+\delta}-\mathrm{CGO}$ composite as cathode on La0.9 $\mathrm{Sr}_{0.1} \mathrm{Ga}_{0.8} \mathrm{Mg}_{0.2} \mathrm{O}_{3-\delta}$ electrolyte for intermediate temperature solid oxide fuel cells. J of Power Sources 2013, 232: 332-337.

[44] Laguna-Bercero MA, Monzón H, Larrea A, et al. Improved stability of reversible solid oxide cells with a nickelate-based oxygen electrode. J Mater Chem A 2016, 4(4): $1446-1453$.

[45] $\mathrm{Gu} \mathrm{H}$, Chen $\mathrm{H}$, Gao L, et al. Electrochemical properties of $\mathrm{LaBaCo}_{2} \mathrm{O}_{5+\delta^{-}}$ $\mathrm{Sm}_{0.2} \mathrm{Ce}_{0.8} \mathrm{O}_{1.9}$ composite cathodes for intermediate-temperature solid oxide fuel cells. 
Electrochim Acta 2009, 54(27): 7094-7098.

[46] Ortiz-Vitoriano N, Bernuy-López C, Hauch A, et al. Electrochemical characterization of $\mathrm{La}_{0.6} \mathrm{Ca}_{0.4} \mathrm{Fe}_{0.8} \mathrm{Ni}_{0.2} \mathrm{O}_{3}$ cathode on $\mathrm{Ce}_{0.8} \mathrm{Gd}_{0.2} \mathrm{O}_{1.9}$ electrolyte for IT-SOFC. Int J Hydrogen Energ 2014, 39(12): 6675-6679.

[47] Han GD, Neoh KC, Bae K, et al. Fabrication of lanthanum strontium cobalt ferrite (LSCF) cathodes for high performance solid oxide fuel cells using a low price commercial inkjet printer. J of Power Sources 2016, 306: 503-509.

[48] Bi L, Boulfrad S, Traversa E. Reversible solid oxide fuel cells (R-SOFCs) with chemically stable proton-conducting oxides. Solid State Ionics 2015, 275: 101-105. 
Table.1 Comparison of $R_{\mathrm{p}}$ values obtained in this study and reported in the literature.

\begin{tabular}{|c|c|c|c|c|c|}
\hline \multicolumn{2}{|l|}{ Electrode } & \multirow[b]{2}{*}{ Electrolyte } & \multicolumn{2}{|c|}{$R_{\mathrm{p}}\left(\Omega \cdot \mathrm{cm}^{2}\right)$} & \multirow{3}{*}{ Reference } \\
\hline \multirow[t]{2}{*}{ composition } & Sintering & & $650^{\circ} \mathrm{C}$ & $750^{\circ} \mathrm{C}$ & \\
\hline & temperature & & & & \\
\hline \multirow{3}{*}{ LNO-GDC } & 900 & GDC & $*$ & 0.244 & \multirow{3}{*}{ [37] } \\
\hline & 1000 & GDC & $*$ & 0.334 & \\
\hline & 1100 & GDC & * & 0.698 & \\
\hline LNO infiltrated YSZ & 850 & YSZ & * & 0.120 & [38] \\
\hline LNO & 900 & SDC & 2.46 & 0.59 & [33] \\
\hline $\mathrm{LNO}+\mathrm{La}_{4} \mathrm{Ni}_{3} \mathrm{O}_{10-\delta}$ & 1000 & LSGM & 1.37 & $*$ & [39] \\
\hline $\mathrm{La}_{1.6} \mathrm{Sr}_{0.4} \mathrm{NiO}_{4}$ nanofibers & 900 & GDC & 0.80 & $*$ & [40] \\
\hline LNO & 1100 & SDC & 0.93 & 0.21 & This work \\
\hline LNO-30LDC & 1100 & SDC & 0.53 & 0.12 & This work \\
\hline
\end{tabular}

* Not reported or could not get precise values 
Figures

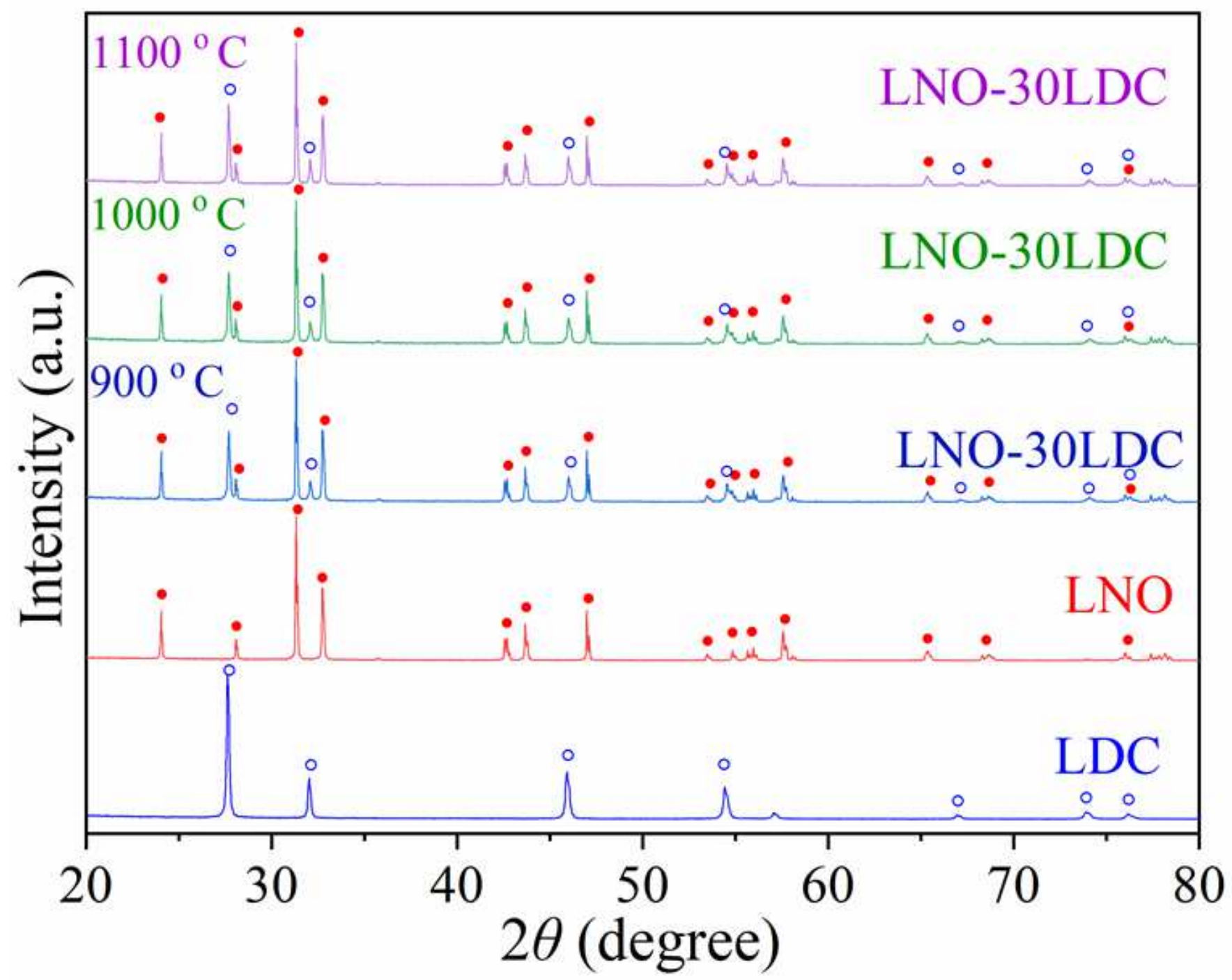

Figure 1

The X-ray diffraction pattern of LNO-30LDC composite after sintered at 900, 1000 and 1100 o C for $10 \mathrm{~h}$. 

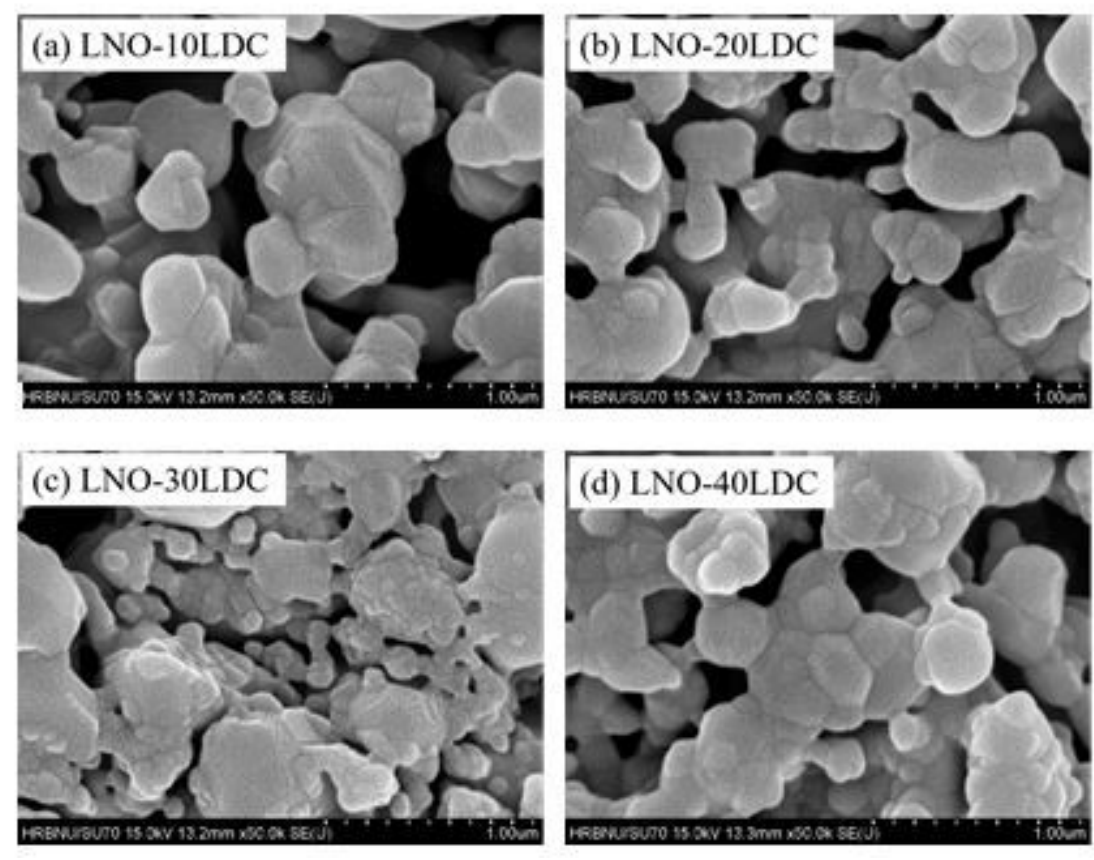

Figure 2

SEM images of electrode surface of samples with different LDC loading $(x=10,20,30,40)$.
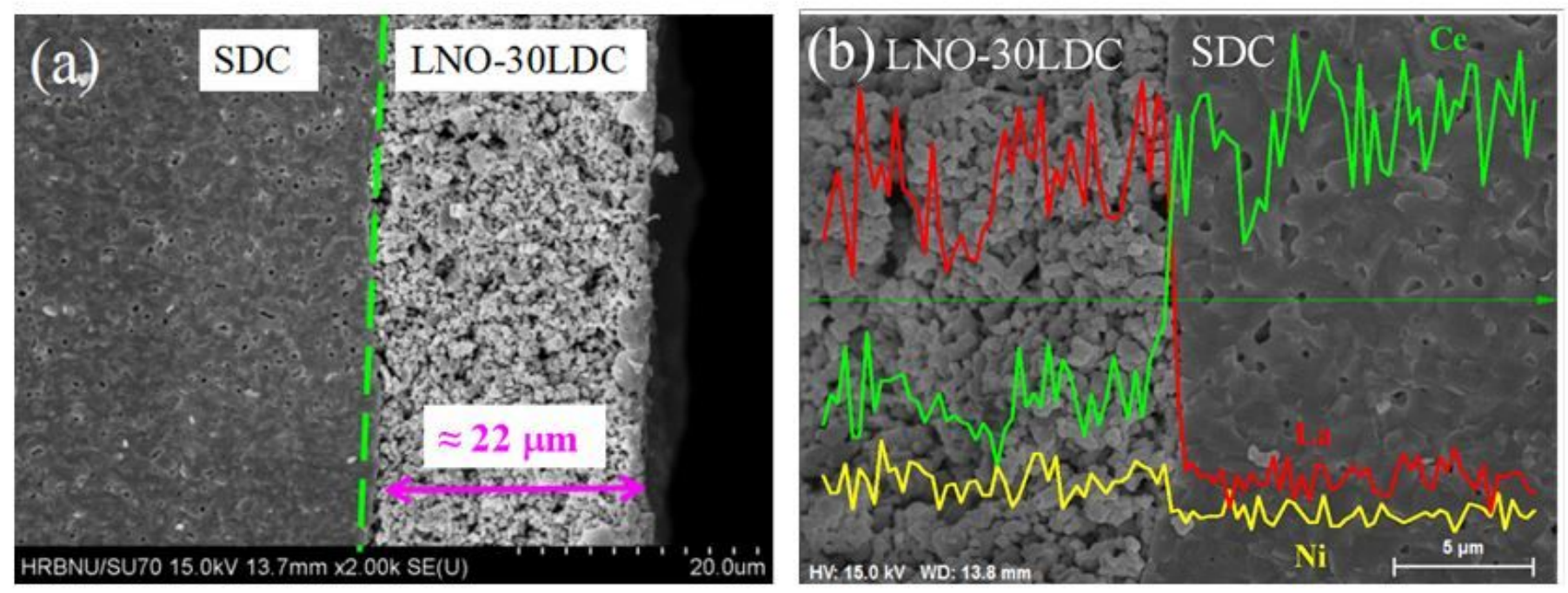

Figure 3

The cross-sectional SEM image (a) and linear scan analysis across the interface (b) of the LNO-30LDC oxygen electrode. 

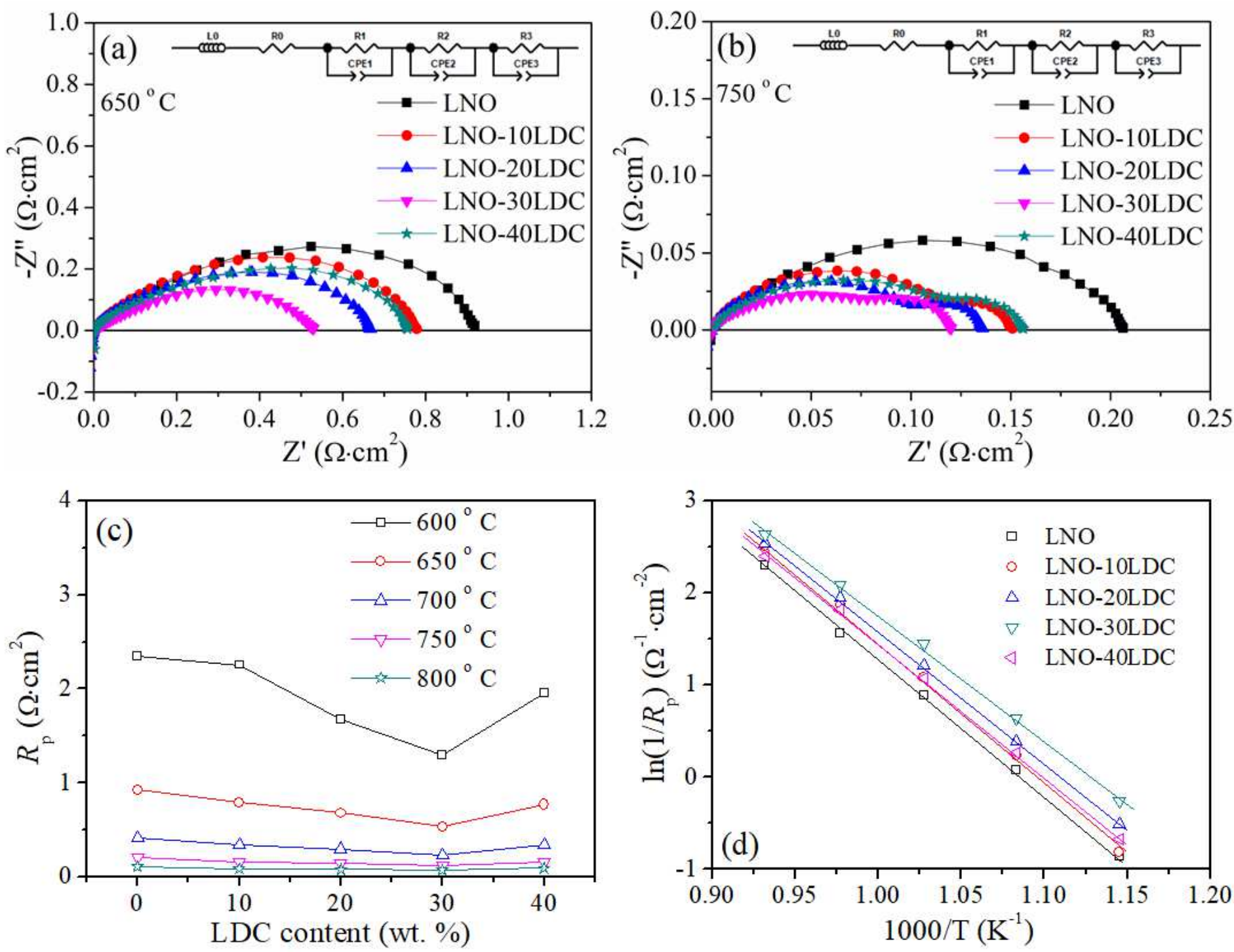

Figure 4

Typical electrochemical impedance spectra of symmetrical cells using LNO-xLDC oxygen electrodes at 650 oC (a) and 750 oC (b); Dependence of Rp (c) and Arrhenius plots (d) for LNO-xLDC oxygen electrodes with different LDC contents at 600 to $800 \mathrm{oC}$ in air. 

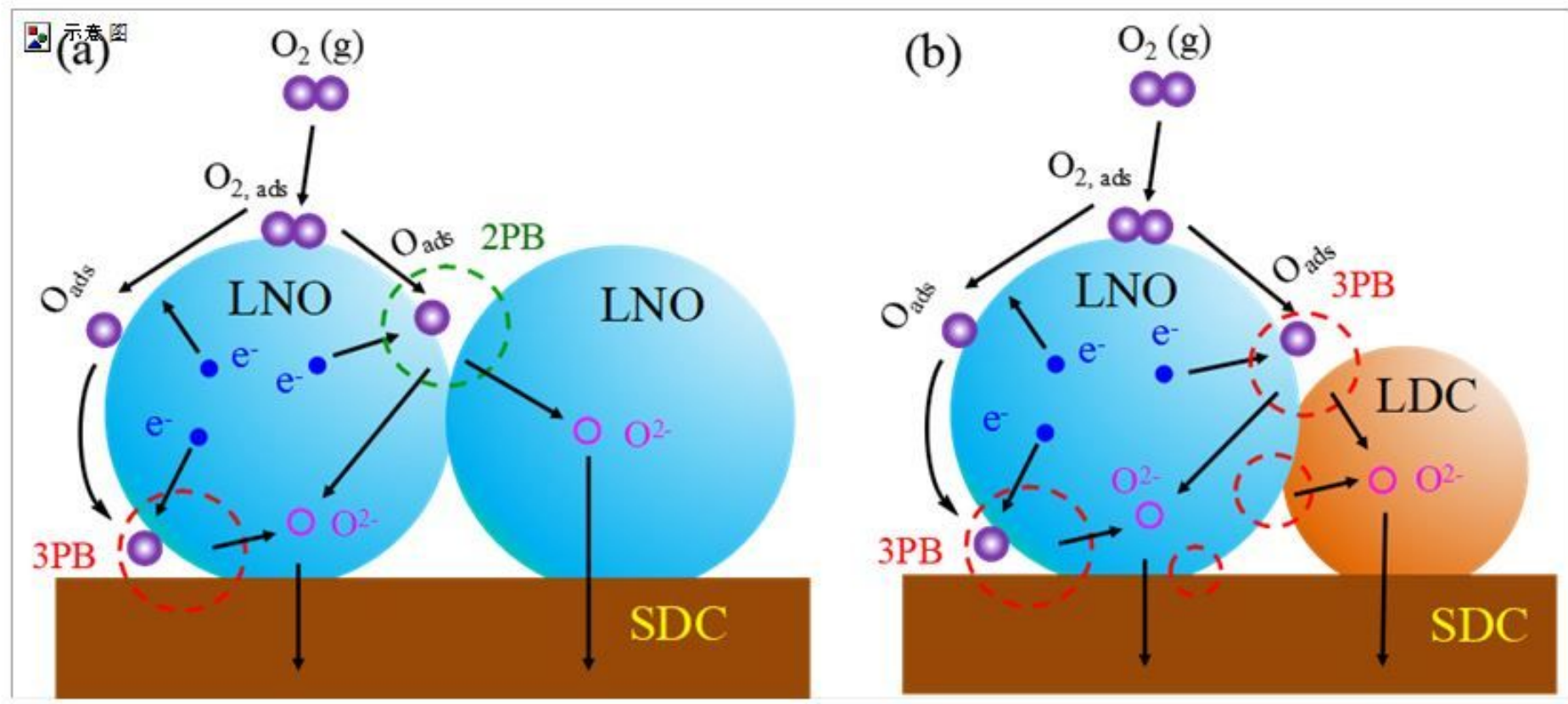

Figure 5

Typical electrochemical impedance spectra of symmetrical cells using LNO-xLDC oxygen electrodes at 650 oC (a) and 750 oC (b); Dependence of Rp (c) and Arrhenius plots (d) for LNO-xLDC oxygen electrodes with different LDC contents at 600 to $800 \mathrm{oC}$ in air.

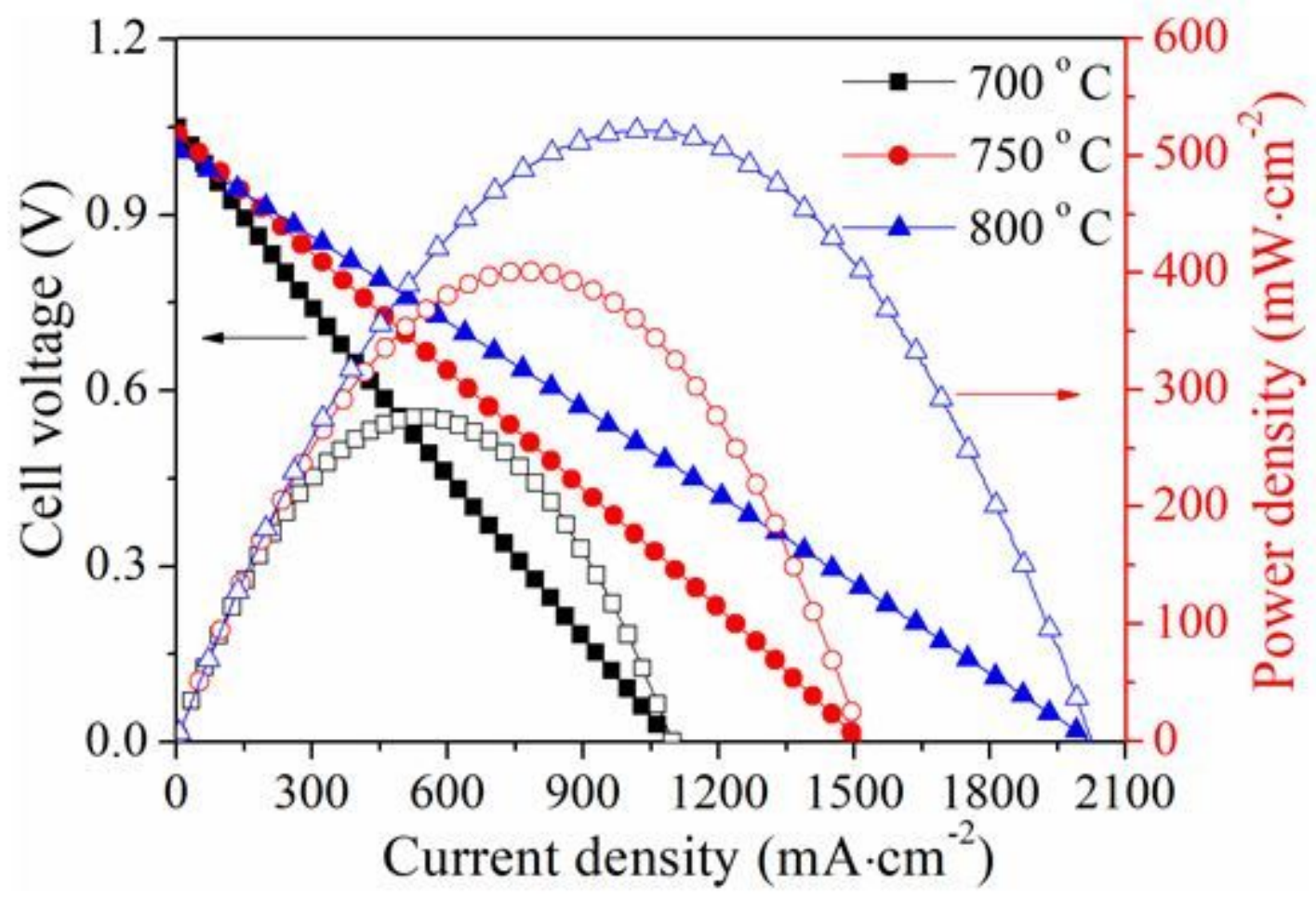

Figure 6 
Typical electrochemical impedance spectra of symmetrical cells using LNO-xLDC oxygen electrodes at 650 oC (a) and 750 oC (b); Dependence of Rp (c) and Arrhenius plots (d) for LNO-xLDC oxygen electrodes with different LDC contents at 600 to $800 \mathrm{oC}$ in air.
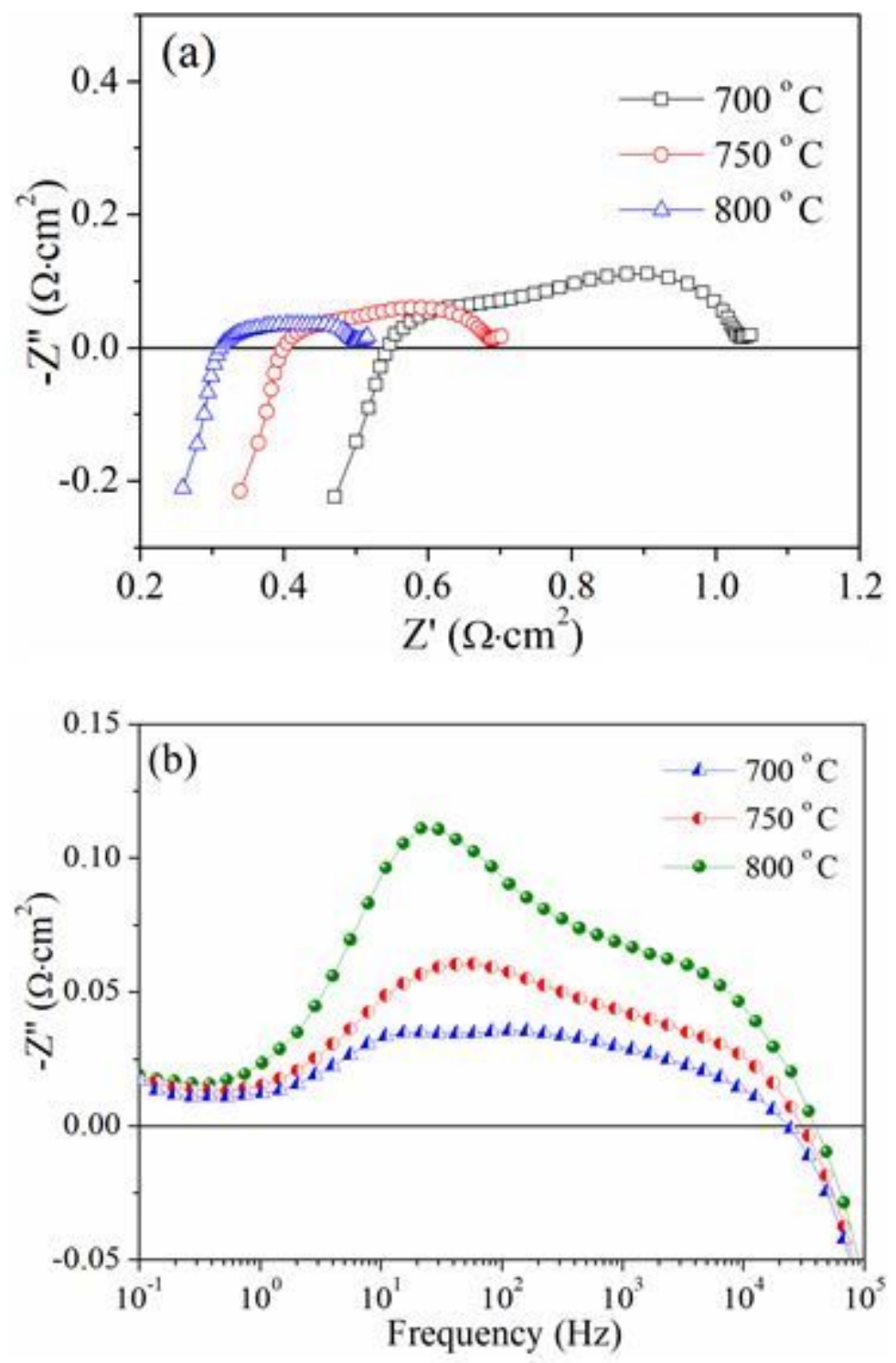

\section{Figure 7}

Typical electrochemical impedance spectra of symmetrical cells using LNO-xLDC oxygen electrodes at 650 oC (a) and 750 oC (b); Dependence of Rp (c) and Arrhenius plots (d) for LNO-xLDC oxygen electrodes with different LDC contents at 600 to 800 oC in air. 

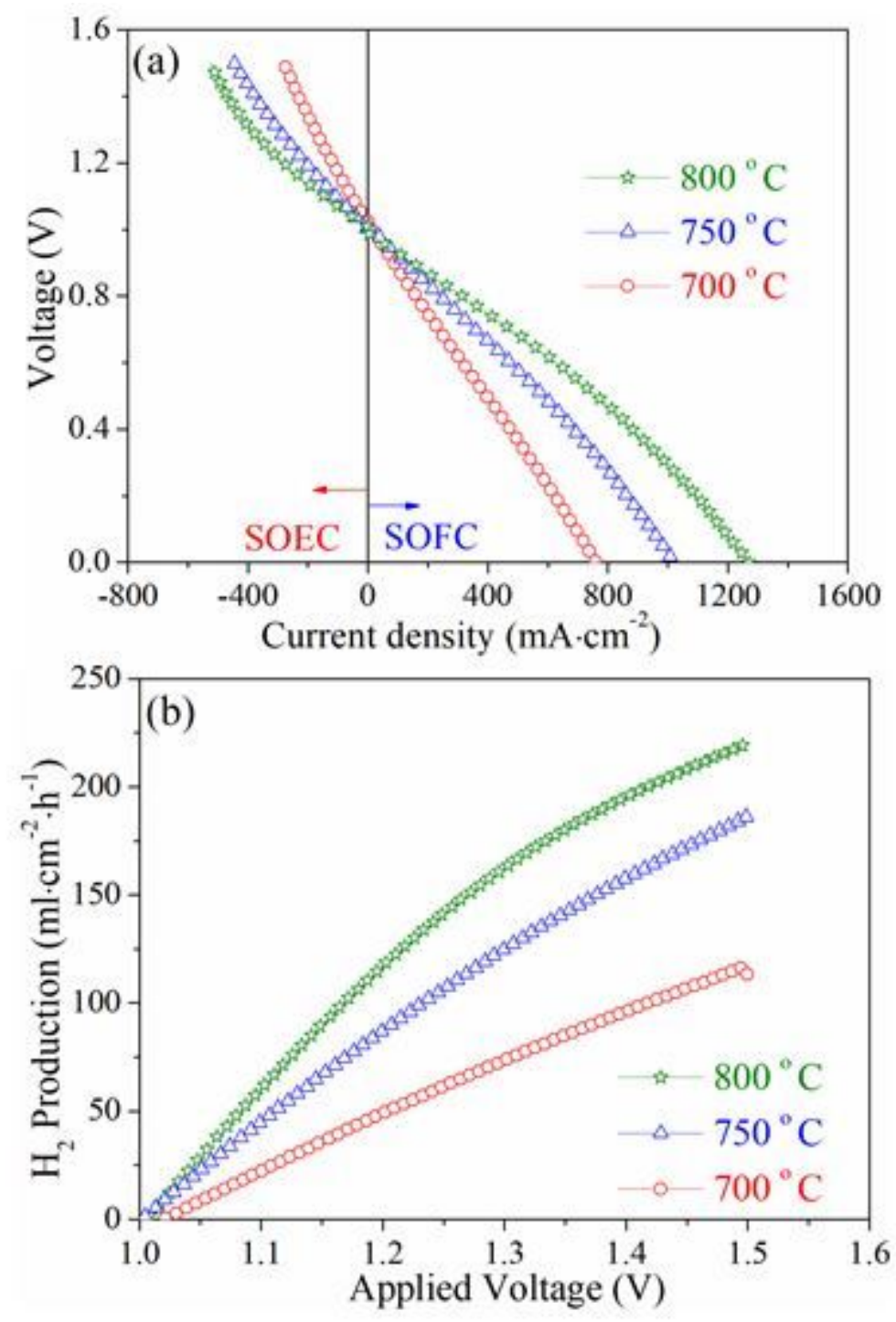

Figure 8

(a) I-V curves of the single cell with LNO-30LDC oxygen electrode operated under SOFC mode and SOEC mode at various temperature; (b) Hydrogen production rates of the cell in SOEC mode at 700-800 oC.

\section{Supplementary Files}

This is a list of supplementary files associated with this preprint. Click to download.

- Supplementarylnformation.doc 